\title{
Fascioliasis in buffaloes: A 5-year forecast analysis of the disease based on a 15-year survey in Brazil
}

\author{
Fasciolose em búfalos: uma análise de previsão de 5 anos da doença com base em uma \\ pesquisa de 15 anos no Brasil
}

Izanara Cristine Pritsch ${ }^{1}$; Emanoelli Cristini Augustinhak Stanula ${ }^{1}$; Alan dos Anjos ${ }^{1}$; José Alberto Bertot ${ }^{2}$; Marcelo Beltrão Molento ${ }^{1,3 *}$ (D)

\author{
${ }^{1}$ Laboratório de Doenças Parasitárias, Departamento de Patologia Básica, Universidade Federal do Paraná - UFPR, Curitiba, PR, Brasil \\ ${ }^{2}$ Laboratório de Bioquímica, Departamento de Medicina Veterinária, Universidad de Camagüey Ignacio Agramonte Loynaz, \\ Camaguey 74569, Cuba \\ ${ }^{3}$ Instituto Nacional de Ciência e Tecnologia, Belo Horizonte, MG, Brasil
}

Received February 25, 2019

Accepted April 29, 2019

\begin{abstract}
In South America, fascioliasis caused by the trematode Fasciola hepatica is an anthropozoonosis disease associated with significant economic losses and poor animal welfare. The objective of this study was to determine the prevalence of $F$. hepatica in the liver of buffaloes slaughtered from 2003 to 2017 in Brazil, and to perform a forecast analysis of the disease for the next five years using the Autoregressive Integrated Moving Average (ARIMA) model. Data analysis revealed an incidence of 7,187 cases out of 226,561 individuals. The disease presented a considerable interannual variation $(\mathrm{p}<0.005)$. Fasciola hepatica was more prevalent in the southern states of Brazil; Paraná, Rio Grande do Sul, and Santa Catarina, presenting 11.9, 7.7, and 3.2\% of infected livers, respectively. The high frequency of liver condemnation in Paraná was influenced by weather conditions. The ARIMA models calculated a constant trend of the disease, depicting an average of its future prevalence. The models also described a worse-case and a positive-case scenario, calculating the effects of intervention measurements. In reality, there is an urgent need for regular diagnostic in the animals (fecal and immune diagnose) and in the environment (intermediate host), in order to avoid the high rates of infection.
\end{abstract}

Keywords: Fasciola hepatica, trematoda, ruminants, epidemiology.

\section{Resumo}

Na América do Sul, a fasciolose causada pelo Trematoda Fasciola hepatica é uma antropozoonose associada a perdas econômicas significativas e baixo grau de bem-estar animal. O objetivo deste estudo foi determinar a prevalência de F. hepatica no fígado de búfalos abatidos entre 2003 a 2017, e realizar uma análise de previsáo da doença para os próximos cinco anos, utilizando o modelo Auto-Regressivo Integrado de Médias Móveis (ARIMA). A análise dos dados revelou uma incidência total de 7.187 casos em 226.561 indivíduos. Houve um acentuado grau de variação interanual nas taxas de prevalência $(\mathrm{p}<0,005)$. Fasciola hepatica foi mais prevalente nos estados do sul do Brasil; Paraná, Rio Grande do Sul e Santa Catarina, com 11,9; 7,7; e 3,2\% de fígados condenados, respectivamente. A alta incidência de condenação de fígado no Paraná foi influenciada pelo fator climático. Os modelos ARIMA indicaram uma tendência constante na ocorrência da doença, destacando um padrão futuro da doença. Os modelos também descreveram cenários de piora e de possível melhoria, calculando os efeitos de medidas de intervençáo. Assim, existe a urgência de realizar diagnóstico constante nos animais (coprológico e diagnóstico imunológico) e no ambiente, para que se evite os altos índices de infecção.

Palavras-chave: Fasciola hepatica, trematoda, ruminantes, epidemiologia.

\section{Introduction}

Fascioliasis is a worldwide anthropozoonotic food and water-borne disease, caused by the trematodes Fasciola hepatica and F. gigantica. The common liver fluke, F. hepatica,

*Corresponding author: Marcelo Beltrâo Molento. Laboratório de Doenças Parasitárias, Departamento de Medicina Veterinária, Universidade Federal do Paraná - UFPR, Rua dos Funcionários, 1540, CEP 80060-000, Curitiba, PR, Brasil. e-mail: molento@ufpr.br. is mainly found in large ruminants in the Americas and requires fresh water Gastropoda snails, such as Lymnaea spp., as an intermediate host (BEESLEY et al., 2018; IBRAHIM, 2017). The severity of the disease affects various animals to different extents, depending of the host species and parasitic burden. The welfare condition and clinical signs can also vary from an asymptomatic infection to a devastating disease 
(weight loss, reduced milk yield, and reproductive failure), including death (EL-TAHAWY et al., 2018; IBRAHIM, 2017; KAPLAN, 2001; SCHWEIZER et al., 2005). In some South American countries, fascioliasis is highly endemic in humans (RODRÍGUEZ-ULLOA et al., 2018), but essentially neglected in others (PRITSCH \& MOLENTO, 2018), with more than 60 million people living in affected areas.

Considering the several characteristics of fascioliasis lifecycle, it can be classified as a disease that is susceptible to the impacts of climatic variations. Studies have shown the influence of the weather on fascioliasis infection in cattle (BENNEMA et al., 2014, 2017; DUTRA et al., 2010). An increase in rainfall was strongly correlated with a higher occurrence of the disease in southern Brazil (DUTRA et al., 2010). Also in Brazil, Silva et al. (2016) reported that a La Nina event affected the positivity index of bovine fascioliasis through significant changes in air temperature and rainfall regimens.

The correlation between a disease and its geographic and climatic location is possible with the use of geographic information systems, creating epidemiological maps for viewing and evidencing risk factors. Based on these tools, Bennema et al. (2017), using a range of isothermality, showed that a large part of Brazil is suitable for $F$. hepatica. Aleixo et al. (2015), using a kernel analysis, determined the density of livers infected with F. hepatica in Brazil from 2003 to 2008, identifying the localities with higher prevalence of fascioliasis in cattle. Geo-environmental analysis system, considering precipitation, temperature, elevation, slope, soil type and land use was used in Espírito Santo, Brazil for mapping the risk of fascioliasis indicating that over $50 \%$ of the southern of the state is either at high or very high risk for fascioliasis (MARTINS et al., 2012).

Domestic buffaloes (Bubalus bubalis), also known as river/water buffaloes, are important to local economies and are present in a small segment of the society. In South America, the most common buffaloes are the Murrah, Mediterranean, Jaffarabadi, and their crosses, which are used for milk and meat production. Only $2 \%$ of the world's water buffalo population (168 million) is in South America, and of this, 77\% (aprox. 1,190 million) is in Brazil (FAO, 2018; IBGE, 2006; BRASIL, 2018). Reports of F. hepatica occurrence in buffaloes were found with positivity rates of 24.7\% (SERRA-FREIRE \& NUERNBERG, 1992), 2.5\% (PILE et al., 2001), 46.7\% (CARNEIRO et al., 2010) and $23.8 \%$ (CARNEIRO et al., 2013), when using fecal exams in Brazil. The occurrence of $F$. hepatica in condemned livers of buffaloes was determined in the state of Rio Grande do Sul (RS). The occurrence rate was $20 \%$, and from that, $81 \%$ of the animals had up to two years of life (MARQUES \& SCROFERNEKER, 2003).

The objectives of the present study were, (1) to determine the prevalence and geographical distribution of $F$. hepatica (from infected livers) in buffaloes across Brazil, and (2) to run a 5-year forecast analysis of the disease for the states of Paraná (PR) and RS.

\section{Materials and Methods}

\section{Study area}

Brazil is geographically located between the parallels latitude $5^{\circ} 16^{\prime} 19^{\prime \prime}$ north, $33^{\circ} 45^{\prime} 09^{\prime \prime}$ south and longitude $34^{\circ} 45^{\prime} 54^{\prime \prime}$ east, and $73^{\circ} 59^{\prime} 32^{\prime \prime}$ "west. The country's total area is $8,515,759.090 \mathrm{~km}^{2}$, distributed among the 5,570 municipalities of the 26 states and one Federal District (IBGE, 2015).

\section{Data collection}

The data was collected from a Brazilian slaughterhouse database of the Meat Inspection Department, under the Federal Inspection Service of the Ministry of Agriculture (MAPA). This data included the total number of slaughtered buffaloes and the livers condemned by $F$. hepatica (parasites had to be visualized after incisions in the organ), from all Brazilian municipalities from 2003 to 2017.

Climate data (precipitation, maximum, minimum and average temperature) were collected from the National Institute of Meteorology (NIM) database, for the states of PR and RS, for the entire period. Three weather stations per state were selected to collect the monthly rainfall and mean temperature.

\section{Data analysis}

A frequency analysis of the municipalities was carried out on the collected data, encoded in Microsoft Excel, using SPSS Version 22.0 (IBM, New York, USA). The frequency of liver condemnation was calculated using Software R 3.5.1 based on the following equation (Equation 1), for each state and year:

$$
\text { Frequency }=\left(\frac{\text { Liver condemnations }}{\text { Slaughtered animals }}\right) \times 100
$$

Kernel density estimation (6-km scale) (ALEIXO et al., 2015) and point cluster analyses were used to calculate the density and space distribution of infected livers, respectively, using QGIS 3.2.2 software.

Linear regression models, using Software R 3.5.1, were used to determine the possible influence of the mean values of abiotic factors (temperature and accumulated precipitation) for each of the four calendar seasons on the number of liver condemnations due to fascioliasis in each respective period.

\section{Forecast model}

The Autoregressive Integrated Moving Average (ARIMA) was adopted for the development of the models. The variables "slaughtered animals" and "condemned livers" were used to calculate the infection ratio to model the incidence of $F$. hepatica for PR and RS. The variables "year" and "month" were created, and seasonal decomposition was performed according to the observed sequences of data, using the equation (Equation 2): 


$$
\mathrm{Yt}=\mathrm{TCt} \times \mathrm{St} \times \mathrm{It}
$$

Where: Yt is the time series (slaughtered animals, condemned livers, and forecasting ratio); TCt is the trend-cycle component; St is the seasonal component; and It is the irregular or random component. The equation's best fits were chosen according to the $\mathrm{R}^{2}$ value. For the forecast analysis, IBM SPSS Statistics software version 21 was used.

\section{Results}

Even though all 26 Brazilian states were included in the study, according to the MAPA database, only 15 states provided records of slaughtered buffaloes during the last 15 years. Out of these, most of the states $(n=11)$ had low incidence and discontinuous official records for the disease (data not shown). Figure 1 describes the location of municipalities and intensity in which the condemned livers were consistently registered. The average prevalence of F. hepatica infection in slaughtered buffaloes was approximately $3 \%(7,187 / 226,561)$, ranging from $1.5 \%$ in 2015 to $6.8 \%$ in 2012 ( $\mathrm{p}<0,005)$. The highest levels of infected livers were in PR, RS, Santa Catarina (SC), and Sáo Paulo (SP), with prevalences of $11.9,7.7,3.2$ and $1.42 \%$, respectively. The frequency of liver condemnations in these states during the last 15 years is shown in Figure 2. The highest rates of condemned livers were observed in PR, $43.7 \%$ in 2016 and $33.6 \%$ in 2012, and in RS $(32.8 \%$ in 2010). SC and SP presented their highest prevalence rates in 2006 (15.8 and $1.9 \%$, respectively).

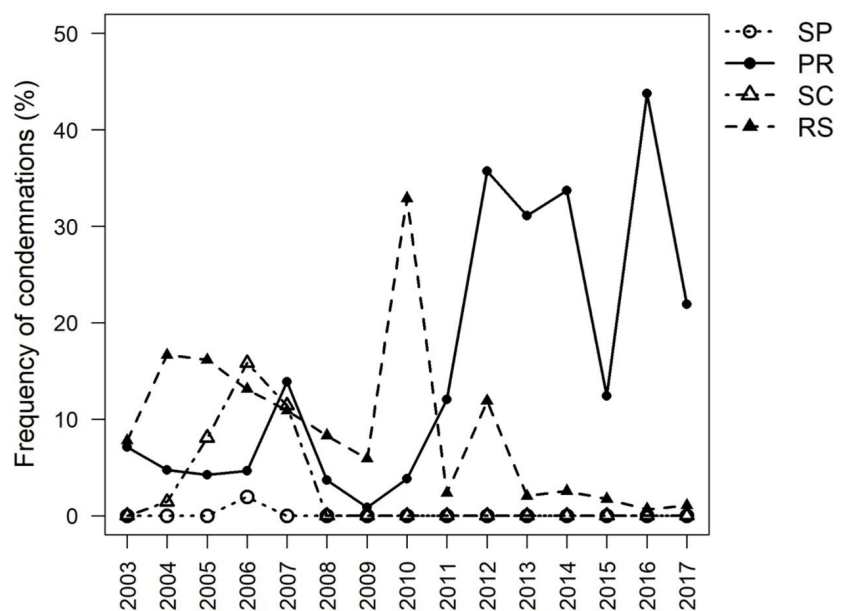

Figure 2. Frequency of liver condemnations by Fasciola hepatica of slaughtered buffalos from 2003 to 2017 per state (SP, São Paulo; PR, Paraná; SC, Santa Catarina; RS, Rio Grande do Sul).

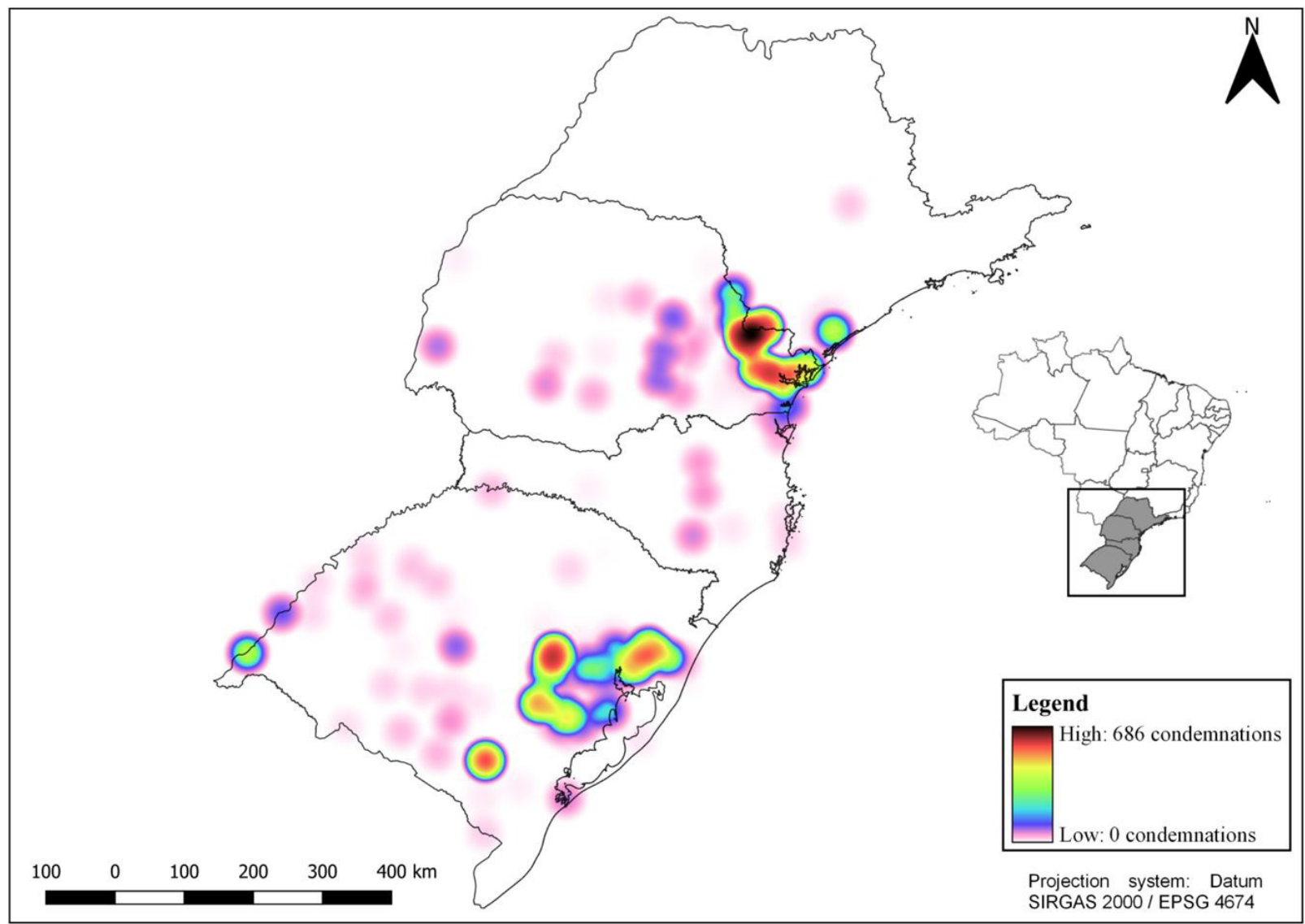

Figure 1. Map of the South of Brazil, including the state of São Paulo, and the density of condemned livers by Fasciola hepatica using Kernel analysis. Data provided by the Federal Inspection Service, MAPA from 2003 to 2017, according to the municipalities of Brazil. $0=$ Absence of condemned livers. $686=$ maximum number of condemned livers. 
The absolute frequency analysis per city from the four states described the number of repetitive occurrences of infected livers over the 15-year period. The cities with the highest repeatability frequencies are in PR: Adrianópolis (14/15), Guaraqueçaba (12/15), Antonina (11/15), Cerro Azul (10/15) and Doutor Ulysses (10/15). Three of these cities (Adrianópolis, Cerro Azul, Doutor Ulysses) are situated in the Ribeira Valley, east of PR, which is one of the most important locations for $F$. hepatica occurrence with a rainfall of $180 \mathrm{~mm}$ during the wettest months.

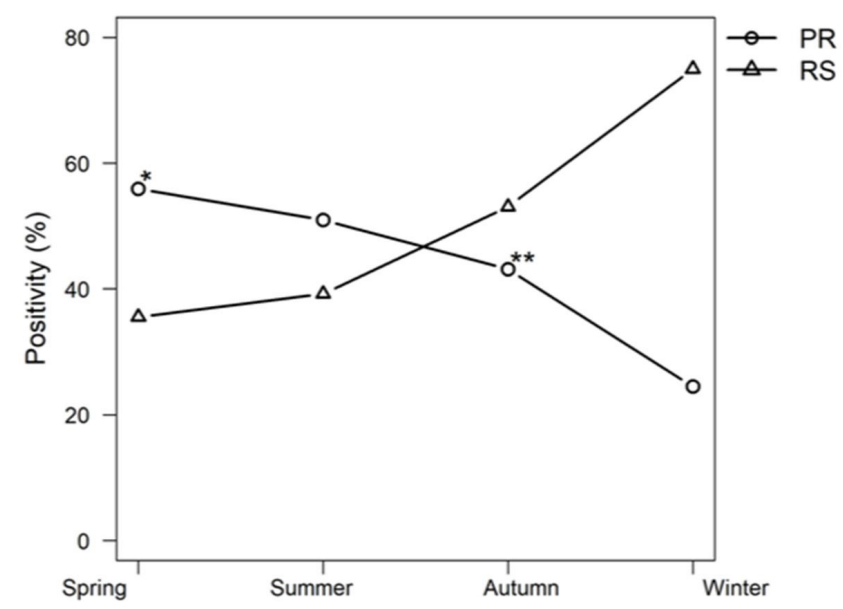

Figure 3. Influence of rainfall and temperature on the percentage of condemned livers by F. hepatica in Parana (PR) and Rio Grande do Sul (RS) states from 2003 to 2017, according to the Southern hemisphere seasons. ${ }^{*}$ Temperature $(\mathrm{p}<0.05)$; ${ }^{* *}$ Rainfall $(\mathrm{p}<0.05)$.
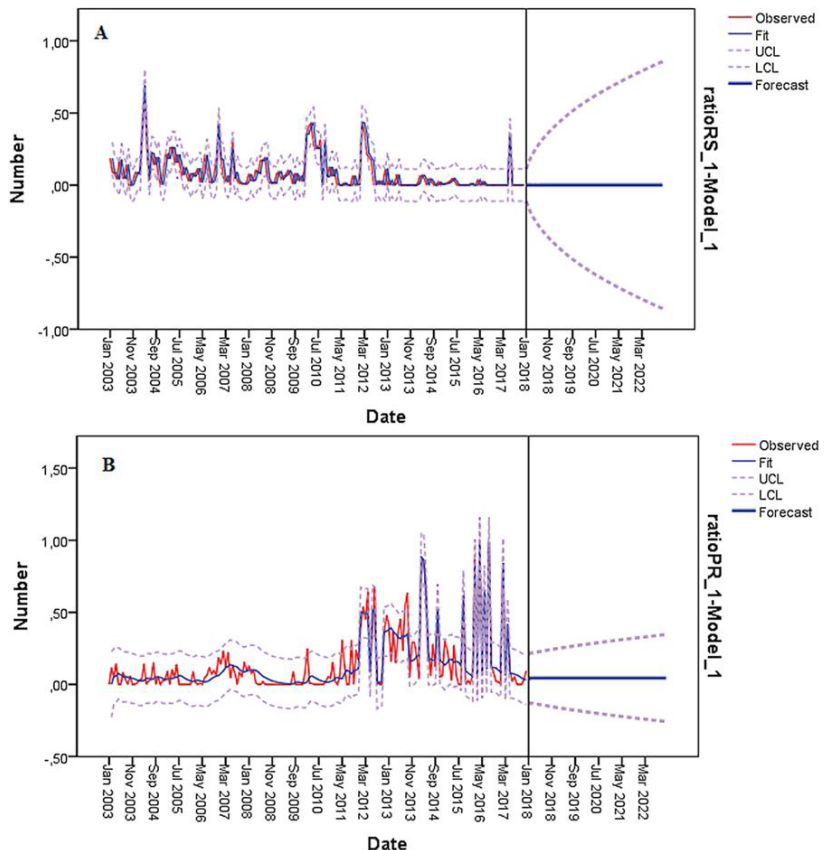

Figure 4. Observed sequence of the condemned livers from 2003 to 2017 and forecast models until 2022 (thick blue line) for Rio Grande do Sul (A) and Parana (B), Brazil. Fit: adjusted model; UCL: upper confidence limit; LCL: lower confidence limit.
Regarding climatic conditions, F. hepatica infection in buffaloes was found to be most influenced by rainfall in the autumn $\left(\mathrm{F}=8.305, \mathrm{p}<0.05, \mathrm{R}^{2}: 0.419\right)$, and temperature in spring $(\mathrm{F}=4.85$, $\left.\mathrm{p}<0.05, \mathrm{R}^{2}: 0.35\right)$. Both factors presented a statistically significant relationship $(\mathrm{p}<0.05)$ with liver condemnation of fascioliasis in PR. None of the abiotic factors were significantly linked to liver condemnation in RS (Figure 3).

The forecast of the disease prevalence for the next 5 years is shown in Figure 4A for RS and $4 \mathrm{~b}$ for PR. The best fit ARIMA model for $R S$ was ARIMA $(0,1,2) \times(2,0,2)$, presenting: $R^{2}=0.751$; Stationary $\mathrm{R}^{2}=0.701 ; \mathrm{RMSE}=0.057$; $\mathrm{MAPE}=98.987$; and a Normalized BIC -5.395. The best fit ARIMA model for PR was ARIMA $(0,1,2)$, presenting an $R^{2}=0.847$; Stationary $\mathrm{R}^{2}=0.847$; $\mathrm{RMSE}=0.087 ; \mathrm{MAPE}=92.365$; and a Normalized $\mathrm{BIC}=-4.356$. Both models are presented with future projections for the occurrence/prevalence of $F$. hepatica in livers.

\section{Discussion}

The present study showed a nationwide average prevalence of $3 \%$ in buffaloes with its highest frequencies occurring in PR (11.9\%) and RS (7.7\%). Buffaloes in PR were observed to be raised in different pasture areas from cattle (e.g. marshy pastures vs. seeded). While epidemiological studies in livestock and humans have been overlooked in many countries, the present work seeks to raise awareness of this important disease, particularly to the large population of buffaloes in Brazil. In cattle, previous studies have also shown that the prevalence of fascioliasis was mainly in the southern states (ALEIXO et al., 2015; DUTRA et al., 2010; SILVA et al., 2016), with an economic loss of approximately US\$ 210 million/year (MOLENTO et al., 2018). Bennema et al. (2017) have also determined that the best suitability area for F. hepatica development, based on a range of isothermality data was the south region of the country. Other studies have also investigated the climate effects and surveillance data for fascioliasis in Europe (CAMINADE et al., 2015; NOVOBILSKÝ et al., 2015).

Dracz \& Lima (2014) reported the first case of naturally infected indigenous buffaloes in the state of Minas Gerais. The study emphasized the ability of the parasite to disperse to municipalities in this state that previously were considered to be free from infection. Similarly, Pile et al. (2001) published the first report of fascioliasis in buffaloes in the state of Rio de Janeiro, registering an occurrence rate of $2.5 \%$. Although the largest buffalo herds in Brazil are located in the states of Pará and Amapá, North of Brazil (BRASIL, 2015), the lack of data from liver inspection from these and other states, complicates a broader analysis. This is mainly due to the scattered data collection and our deficient databank, which should combine the different levels of slaughterhouse inspection (Federal, State and Municipal) (BENNEMA et al., 2014). According to Collins (1996), the abattoir surveillance has also some limitations such as inspection line, light intensity, the inspector's experience and motivation.

PR has two major climate classifications: Cfa with hot summers; and Cfb with mild temperate summers (ALVARES et al., 2014). The disease occurrence falls almost entirely under the $\mathrm{Cfb}$ area of $\mathrm{PR}$, and according to the absolute frequency analyzed for the buffalo 
infections, the cities with a highest fascioliasis repeatability were in that area (Figure 1 and 3), suggesting that the biological lifecycle of the parasite is well established. Whereas the prevalence cases in RS occurred almost entirely under the Cfa climatic conditions. Both states had similar annual rainfall (PR: 1300 - 2200 mm/year; and RS: 1600 - $2200 \mathrm{~mm} /$ year). Annual air temperature was also comparable between the two regions (data not shown), but there was a considerably larger difference in land elevation between PR (100 to 1200 m.a.s.l.) and RS (100 to 400 m.a.s.l.).

We believe that $F$. hepatica is well established in buffaloes in $\mathrm{PR}$ and RS, even considering all the environmental (climate over the years) and topographical differences between the regions. The influence of rainfall and temperature on the percentage of condemned livers during the period of the study was evaluated according to the seasons of the year. Due to the relatively high prevalence observed in the states of PR and RS, the influence of the weather was further investigated in these areas. For PR, the data revealed that $F$. hepatica infection in buffaloes was influenced by the increase in rainfall and temperature in autumn and spring, respectively, since the increase of these factors tended to decrease the number of liver condemnations. On the other hand, no weather influence was related to the liver condemnation in RS. Dutra et al. (2010) reported that temperature did not reveal significant changes in high risk areas for F. hepatica infection in cattle, while altitude was found to be a significant determinant of the disease prevalence. Byrne et al. (2016) also found variable associations between long-term climate conditions and condemnation rates of liver infection in cattle, adding that long-term weather variation, geographic location and herd-type were important risk factors. Byrne et al. (2018) found a significant seasonal variation of $F$. hepatica antibodies in dairy herds in Northern Ireland, reporting the highest infection rate in winter, whilst the lowest rates were found during the summer. In this line, Gosling et al. (2011) estimated that an increase in temperature of up to $3.5^{\circ} \mathrm{C}$ in Brazil, and based on the above facts, there will be a large chance that risk areas for fascioliasis will spread around new areas. The International Panel on Climate Change (CLINE, 2007) reported that countries in Latin America may observe an increase in disease incidence, due to the increase of inundation and specific vectors. Therefore, the increase in temperature and precipitation will change the prevalence of fascioliasis, as was also determined in Brazil by Bennema et al. (2017) and Dutra et al. (2010). Silva et al. (2016) noted that La Nina years affected bovine fascioliasis (temperature and rainfall).

Our predictive models developed for this study forecasted a constant trend of the disease over the next 5 years, indicating that intervention measurements must be adopted to reduce parasite prevalence, liver lesions, and economic losses, improving animal welfare. Otherwise, the negative pattern of the disease will remain above the $10 \%$ prevalence in endemic areas, or in the worse-case scenario, the disease could be more intense, further aggravating the situation. The model also predicted a possible positive scenario, which would represent an improvement in nationwide herd health conditions.

After determining the high prevalence of $F$. hepatica in the south of the country, we urge to suggest that preventive measures (i.e. diagnosis, disease monitoring) must be regularly made. The negative impact of the disease could then be reduced, while also decreasing the threat of spreading fascioliasis to humans. Furthermore, we see that our models can be used as the basis for monitoring fascioliasis in other endemic areas in South America and the Caribbean, implementing a disease surveillance program. This is an urgent requirement, as the collected data has demonstrated a potential risk to millions of people and animals.

\section{Conclusions}

Our study has determined for the first time the spacial distribution and the occurrence rates of fasciolosis in buffaloes for Brazil. The data revealed high prevalence rates in the states of PR and RS, demonstrating that the disease is widespread in two distinct geographical and climatic areas. The forecast models predicted three main conditions, ranging from a positive scenario (lower part of Figure 4/low incidence) up to a worrisome future trend (higher part of the same Figure/high incidence). A condition to understand the present data is the need to recognize the existing low sanitary condition of water buffaloes in Brazil, and the necessity to improve the herd health. The use of the ARIMA models may work as an important instrument to help establish future preventive strategies for $F$. hepatica infection in water buffaloes under similar management.

\section{Acknowledgements}

The authors wish to thank Coordenação de Aperfeiçoamento de Pessoal de Nível Superior - CAPES/MES CUBA for the visit of Prof. J. A. Bertot. Ms. I. Pritsch was awarded a doctoral fellowship from CAPES.

\section{References}

Aleixo MA, Freitas DF, Dutra LH, Malone J, Martins IVF, Molento MB. Fasciola hepatica: Epidemiology, perspectives in the diagnostic and the use of geoprocessing systems for prevalence studies. Semina: Ciênc Agrár 2015; 36(3): 1451-1465. http://dx.doi.org/10.5433/16790359.2015v36n3p1451.

Alvares CA, Stape L, Sentelhas PC, Gonçalves JLM, Sparokev G. Koppen's climate classification map for Brazil. Meteorol Z (Berl) 2014; 22(6): 711 728. http://dx.doi.org/10.1127/0941-2948/2013/0507.

Beesley NJ, Caminade C, Charlier J, Flynn RJ, Hodgkinson JE, MartinezMoreno A, et al. Fasciola and fasciolosis in ruminants in Europe: Identifying research needs. Transbound Emerg Dis 2018; 65(Suppl. 1): 199-216. http://dx.doi.org/10.1111/tbed.12682. PMid:28984428.

Bennema SC, Molento MB, Scholte RG, Carvalho OS, Pritsch I. Modelling the spatial distribution of Fasciola hepatica in bovines using decision tree, logistic regression and GIS query approaches for Brazil. Parasitology 2017; 144(13): 1677-1685. http://dx.doi.org/10.1017/ S0031182017000786. PMid:28805164.

Bennema SC, Scholte RGC, Molento MB, Medeiros C, Carvalho OS. Fasciola hepatica in bovines in Brazil: data availability and spacial distribution. Rev Inst Med Trop São Paulo 2014; 56(1): 35-41. http:// dx.doi.org/10.1590/S0036-46652014000100005. PMid:24553606. 
Brasil. Ministério da Agricultura, Pecuária e Abastecimento. Serviço Inspeção Federal. [online]. Brasília: MAPA; 2018 [cited 2018 Mar 03]. Available from: http://www.agricultura.gov.br/MAPA.

Brasil. Ministério da Agricultura. Pecuária e Abastecimento. Dados de rebanho bovino e bubalino do Brasil. [online]. Brasília: MAPA; 2015 [cited 2018 Mar 03]. Available from: http://www.agricultura.gov.br/arq_editor/ file/ copy_of_DadosderebanhobovinoebubalinonoBrasil_2015.pdf

Byrne AW, Graham J, McConville J, Milne G, McDowell S, Hanna REB, et al. Seasonal variation of Fasciola hepatica antibodies in dairy herds in Northern Ireland measured by bulk tank milk ELISA. Parasitol Res 2018; 117(9): 2725-2733. http://dx.doi.org/10.1007/s00436-0185961-0. PMid:29948207.

Byrne AW, McBride S, Lahuerta-Marin A, Guelbenzu M, McNair J, Skuce RA, et al. Liver fluke (Fasciola hepatica) infection in cattle in Northern Ireland: a large-scale epidemiological investigation utilising surveillance data. Parasit Vectors 2016; 9(1): 209. http://dx.doi.org/10.1186/s13071016-1489-2. PMid:27079910.

Caminade C, van Dijk J, Baylis M, Williams D. Modelling recent and future climatic suitability for fasciolosis in Europe. Geospat Health 2015; 9(2): 301-308. http://dx.doi.org/10.4081/gh.2015.352. PMid:25826311.

Carneiro MB, Alves DP, Donatele DM, Pereira OS Jr, Martins IVF. Fasciola hepatica em ovinos, caprinos e bubalinos em municípios do sul do Espírito Santo. Arq Inst Biol 2013; 80(4): 442-446. http://dx.doi. org/10.1590/S1808-16572013000400011.

Carneiro MB, Bernardo CC, Júnior AC, Alves DP, Pereira OS Jr, Martins I. Fasciola hepatica em búfalos (Bubalus bubalis) no Sul do Espírito Santo. Rev Bras Med Vet 2010; 32(2): 89-91.

Cline WR. Global Warming and Agriculture: Impact Estimates by Country. Washington: Center for Global Development, Peterson Institute for International Economics; 2007

Collins JD. Meat plant surveillance and its role in the eradication of tuberculosis in cattle. Dublin: University College Dublin Tuberculosis Investigation Unit; 1996. (Selected Papers). p. 55-59.

Dracz RM, Lima WS. Autochthonous infection of buffaloes and cattle by Fasciola hepatica in Minas Gerais, Brazil. Rev Bras Parasitol Vet 2014; 23(3): 413-416. http://dx.doi.org/10.1590/S1984-29612014054. PMid:25271466.

Dutra LH, Molento MB, Naumann CRC, Biondo AW, Fortes FS, Savio $\mathrm{D}$, et al. Mapping risk of bovine fasciolosis in the south of Brazil using geographic information systems. Vet Parasitol 2010; 169(1-2): 76-81. http://dx.doi.org/10.1016/j.vetpar.2009.12.015. PMid:20071083.

El-Tahawy AS, Kwan N, Sugiura K. Fasciola hepatica infection in water buffalo Bubalus bubalis in three provinces of the Nile Delta, Egypt: a cross-sectional study. J Vet Med Sci 2018; 80(1): 28-35. http://dx.doi. org/10.1292/jvms.17-0282. PMid:29151443.

Food and Agriculture Organization of the United Nations - FAO. Water buffaloes [online]. Rome: FAO; 2018 [cited 2018 Sep 18]. Available from: http://www.fao.org/home/en/
Gosling SN, Dunn R, Carrol F, Christidis N, Fullwood J, Gusmao D, et al. Climate: Observations, projections and impacts. Brazil. Met Office, 2011.

Ibrahim N. Fascioliasis: Systematic Review. Adv Biol Res 2017; 11(5): 278-285. http://dx.doi.org/10.5829/idosi.abr.2017.278.285.

Instituto Brasileiro de Geografia e Estatística - IBGE. Agricultura e Pecuária. [online]. 2015 [cited 2017 Jul 10]. Available from: https:// www.ibge.gov.br/

Instituto Brasileiro de Geografia e Estatística - IBGE. Censo Agropecuário. [online]. 2006 [cited 2018 Jul 02]. Available from: https://www.ibge.gov.br/

Kaplan RM. Fasciola hepatica: a review of the economic impact in cattle and considerations for control. Vet Ther 2001; 2(1): 40-50. PMid:19753697.

Marques SMT, Scroferneker ML. Fasciola hepatica infection in cattle and buffaloes in State of Rio Grande do Sul, Brazil. Parasitol Latinoam 2003; 58(3-4): 169-172. http://dx.doi.org/10.4067/S0717-77122003000300015.

Martins IV, de Avelar BR, Pereira MJ, da Fonseca AH. Application of a geographical information system approach for risk analysis of fascioliasis in southern Espírito Santo state, Brazil. Geospat Health 2012; 6(3): S87-S93. http://dx.doi.org/10.4081/gh.2012.126. PMid:23032288.

Molento MB, Bennema S, Bertot J, Pritsch IC, Arenal A. Bovine fascioliasis in Brazil: Economic impact and forecasting. Vet Parasitol Reg Stud Rep 2018; 12: 1-3. http://dx.doi.org/10.1016/j.vprsr.2017.12.004. PMid:31014798.

Novobilský A, Novák J, Björkman C, Höglund J. Impact of meteorological and environmental factors on the spatial distribution of Fasciola hepatica in beef cattle herds in Sweden. BMC Vet Res 2015; 11(1): 128. http:// dx.doi.org/10.1186/s12917-015-0447-0. PMid:26054940.

Pile E, Santos JAA, Pastorello T, Vasconcellos M. Fasciola hepatica em búfalos (Bubalus bubalis) no município de Maricá, Rio de Janeiro, Brasil. BrazJ Vet Res Anim Sci 2001; 38(1): 42-43. http://dx.doi.org/10.1590/ S1413-95962001000100008.

Pritsch IC, Molento MB. Recount of reported cases of human fascioliasis in Brazil over the last 60 years. Rev Patol Trop 2018; 47(2): 75-85. http:// dx.doi.org/10.5216/rpt.v47i2.53636.

Rodríguez-Ulloa C, Rivera-Jacinto M, del Valle-Mendoza J, Cerna C, Hoban C, Chilón S, et al. Risk factors for human fascioliasis in schoolchildren in Baños del Inca, Cajamarca, Peru. Trans $R$ Soc Trop Med Hyg 2018; 112(5): 216-222. http://dx.doi.org/10.1093/trstmh/ try049. PMid:29860359.

Schweizer G, Braun U, Deplazes P, Torgerson PR. Estimating the financial losses due to bovine fasciolosis in Switzerland. Vet Rec 2005; 157(7): 188-193. http://dx.doi.org/10.1136/vr.157.7.188. PMid:16100368.

Serra-Freire NM, Nuernberg S. Geopolitical dispersion of the occurence of Fasciola hepatica in the State of Santa Catarina, Brazil. Mem Inst Oswaldo Cruz 1992; 87(Suppl. 1): 263-269. http://dx.doi.org/10.1590/ S0074-02761992000500050. PMid:1343793.

Silva AEP, Freitas CC, Dutra LV, Molento MB. Assessing the risk of bovine fasciolosis using linear regression analysis for the state of Rio Grande do Sul, Brazil. Vet Parasitol 2016; 217: 7-13. http://dx.doi.org/10.1016/j. vetpar.2015.12.021. PMid:26827853. 